\title{
POVZETKI, SYNOPSES, ZUSAMMENFASSUNGEN
}

(c) BYSA

Stati in obstati $17(2021): 197-206$

https://doi.org/10.26493/2590-9754.17(33)197-206

UDC $274(497.4) “ 15^{“}: 323.1$

\section{Vanja Kočevar}

Vloga reformacije v slovenski etnogenezi:

etnična kolektivna identiteta na premici zgodovine dolgega trajanja

Čeprav je bila reformacija tako v Evropi kot na Slovenskem v prvi vrsti verske narave, so njeni dosežki pri Slovencih dolgoročno veliko bolj zaznamovali njihovo etnično kot konfesionalno kolektivno identiteto. Deželnoknežja protireformacija je sicer med letoma 1598 in 1628 protestantizem v notranjeavstrijskih deželah odpravila, vendar se je katoliška obnova oprla na nekatere njegove dosežke. Za razvoj Slovencev kot etnične skupnosti so zlasti pomembne štiri reformacijske stvaritve, in sicer: (1) knjižna norma, (2) koncept Slovenske cerkve, (3) mit o etnični izbranosti in (4) topos o velikem obsegu »slovanskega «/slovenskega jezika. V skladu z etnosimbolistično paradigmo zato ocenjujemo, da so se Slovenci v drugi polovici 16. stoletja iz etnične kategorije razvili v etnično mrežo.

Slovenski jezik, ki je bil od konca prvega tisočletja dalje sicer sporadično zapisovan, je na pot knjižnega jezika naposled stopil leta 1550 s prvima knjigama, ki ju je objavil Primož Trubar. Svoj vrh je knjižno delo protestantov doseglo leta 1584, ko sta bila objavljena še Sveto pismo v prevodu Jurija Dalmatina in slovnica izpod peresa Adama Bohoriča. Trubar pa je tudi idejni oče koncepta »Slovenske cerkve«, ki naj bi združevala celotno slovensko govoreče krščansko občestvo. Svojo idejo je Trubar prvič predstavil leta 1555 ter jo dovršil v svoji Cerkovni ordningi iz leta 1564. Idejni program, ki v cerkvenoupravnem pogledu sicer ni zaživel, je nato pomembno zaznamoval miselnost tako protestantskih kot tudi poznejših katoliških piscev v 17. in 18. stoletju.

$\mathrm{V}$ čas reformacije datira tudi vznik slovenskega mita o etnični izbranosti, ki je oprt na stavek iz Pavlovega Pisma Rimljanom, »in vsak jezik bo slavil Boga (Rim 14,11), in kot maksima povezuje ključne knjižne stvaritve obravnavane dobe. Poleg tega so se protestantski pisci oprli na humanistično tradicijo poudarjanja velikega obsega "slovanskega « jezika, kar je dejansko služilo večanju pomena slovenščine. Ta topos je v slovenske slovnice prvi uvedel Bohorič in predstavlja nekoliko poznejši slovenski vstop $\mathrm{v} »(\mathrm{med})$ narodno tekmovanje za nacionalno čast«, ki se je v Evropi razvnelo v času humanizma.

Ključne besede: reformacija, slovenska etnogeneza, knjižna norma, Slovenska cerkev, (proto)nacionalizem 


\section{The Role of the Reformation in Slovene Ethnogenesis: Collective Ethnic Identity in Long-Term History}

Although the Reformation in both Europe and Slovenia was primarily of a religious nature, its long-term impact on Slovenes is much more visible in their collective ethnic than religious identity. While the sovereign Counter-Reformation abolished Protestantism in the Inner Austrian lands between 1598 and 1628, the Catholic Revival used certain achievements of the movement in its own pursuits. For the further development of Slovenes as an ethnic community, especially four Reformation creations are important: 1) the linguistic norm, 2) the concept of the Slovene church, 3) the myth of the chosen ethnicity and 4) a topos about the great extent of the "Slavic"/Slovene language. In accordance with the ethnosymbolist paradigm, the discussion therefore estimates that in the second half of the $16^{\text {th }}$ century Slovenes developed from an ethnic category into an ethnic network.

The Slovene language, which was sporadically written from the end of the first millennium onwards, was finally consolidated as a literary language in 1550 with the first two books published by Primož Trubar. The Protestant literary work reached its peak in 1584, when a translation of the Bible by Jurij Dalmatin and a grammar by Adam Bohorič were published. The concept of the "Slovene church", which is supposed to unite the entire Slovene-speaking Christian community, was also conceived by Trubar. He presented his idea for the first time in 1555 and completed it in his Cerkovna ordninga ("the Church Order") from 1564. Although the conceptual programme was not established in the church administration, it significantly influenced the mindset of both Protestant and later Catholic writers in the $17^{\text {th }}$ and $18^{\text {th }}$ centuries.

The emergence of the Slovene myth of the chosen ethnicity, which is based on a sentence from the Letter of Paul to the Romans: "and every tongue will praise God" (Romans 14:11), also dates back to the Reformation and as a maxim connects the key literary creations of this period. In addition, Protestant writers relied on the humanistic tradition of emphasizing the great extent of the "Slavic" language, which in fact served to increase the importance of Slovene. This topos was first introduced to Slovene grammars by Bohorič and represents a somewhat later entry of Slovenes into the "(inter)national competition for national honor", which emerged in Europe during the humanism.

Keywords: Reformation, Slovene ethnogenesis, linguistic norm, Slovene church, (proto-)nationalism

\section{Die Rolle der Reformation in der slowenischen Ethnogenese: Ethnische kollektive Identität auf der Linie der Langzeitgeschichte}

Obwohl die Reformation sowohl in Europa als auch in den slowenischen Gebieten in erster Linie religiöser Natur war, haben ihre Errungenschaften auf lange Sicht gesehen viel mehr die ethnische und weniger die konfessionelle slowenische kollektive 
Identität geprägt. Durch die landesfürstliche Gegenreformation wurde der Protestantismus in den innerösterreichischen Ländern zwischen 1598 und 1628 zwar abgeschafft, doch stützte sich die katholische Restauration auf einige seiner Errungenschaften. Für die Entwicklung der Slowenen als ethnische Gemeinschaft sind vier reformatorische Errungenschaften besonders wichtig, und zwar: 1) die Norm der Schriftsprache, 2) das Konzept der Slowenischen Kirche, 3) der Mythos von der ethnischen Erwähltheit und 4) der Topos von der großen Reichweite der „slawischen“/slowenischen Sprache. Dem ethnosymbolistischen Paradigma entsprechend wird daher angenommen, dass sich die Slowenen in der zweiten Hälfte des 16. Jahrhunderts von einer ethnischen Kategorie zu einem ethnischen Netzwerk entwickelt haben.

Die ab Ende des ersten Jahrtausends zwar sporadisch niedergeschriebene slowenische Sprache betrat schließlich 1550 mit den ersten von Primož Trubar veröffentlichten Büchern den Weg einer Schriftsprache. Das literarische Schaffen der Protestanten erreichte seinen Höhepunkt im Jahr 1584, als die Bibel-Übersetzung und die Grammatik aus der Feder von Jurij Dalmatin beziehungsweise Adam Bohorič veröffentlicht wurden. Trubar ist des Weiteren auch der Ideenvater des Konzepts der „Slowenischen Kirche", die die gesamte slowenisch sprachige christliche Gemeinschaft vereinen sollte. Seine Ideen stellte Trubar zum ersten Mal 1555 vor und vervollständigte sie in seiner Kirchenordnung (Cerkovna ordninga) aus dem Jahr 1564. Das konzeptionelle Programm, das innerhalb der Kirchenverwaltung zwar nicht umgesetzt wurde, hat daraufhin maßgeblich die Denkart sowohl protestantischer als auch späterer katholischer Schriftsteller des 17. und 18. Jahrhunderts geprägt.

Auch der Ursprung des slowenischen Mythos von der ethnischen Erwähltheit, der sich auf den Satz aus dem Brief des Paulus an die Römer ,und jede Zunge wird Gott preisen“ (Röm 14,11) bezieht, geht auf die Zeit der Reformation zurück und verbindet als Maxime die wichtigsten Buchschöpfungen des behandelten Zeitraums. Darüber hinaus stützten sich protestantische Autoren auf die humanistische Tradition und damit auf die Betonung der breiten Reichweite der „slawischen“ Sprache, was tatsächlich dazu führte, die Bedeutung der slowenischen Sprache zu steigern. Dieser Topos wurde zuerst von Bohorič in die slowenische Grammatik eingeführt und stellt einen etwas späteren slowenischen Einstieg in den „(inter)nationalen Wettbewerb um die nationale Ehre“ dar, der in der Zeit des Humanismus in Europa entflammte.

Schlüsselwörter: Reformation, slowenische Ethnogenese, Norm der Schriftsprache, Slowenische Kirche, (Proto)nationalismus 


\section{UDC 274:929Luther M.}

\section{Vincenc Rajšp}

\section{Ob 500 letnici Luthrovega nastopa na državnem zboru v Wormsu}

Državni zbor v Wormsu predstavlja po objavi Luthrovih tez, 31. oktobra 1517, naslednji temeljni korak v reformnem gibanju evropskega krščanstva 16. stoletja. Tukaj se je v Svetem rimskem cesarstvu odprla pot za nadaljnji verski in nov institucionalni razvoj v dotlej enotni Cerkvi, katere vrhunec predstavlja Augsburški verski mir leta 1555, ki je posameznim vladarjem političnih enot $\mathrm{v}$ državi, knezom, knezoškofom itd. priznal pravico odločanja o veri podložnikov katoliške in luteranske smeri.

Neposreden povod za »Worms 1521 « in posledično »wormški edikt« sta bili dve na Luthra naslovljeni papeški buli, prva z grožnjo ekskomunikacije Exsurge Domine leta 1520, v kolikor ne prekliče slabe polovice leta 1517 objavljenih tez, na katero je odgovoril s tem, da je papeža razglasil za antikrista, čeprav ga je dotlej nekako izvzemal v svoji kritiki, in bulo decembra istega leta javno sežgal. Tej je januarja 1521 sledila bula Decet Romanum Pontificem, s katero je bil Luther ekskomuniciran, kar je pomenilo tudi smrtno obsodbo in državno izobčenje.

Po dotedanjem naziranju in praksi bi sledila avtomatična izvršitev kazni. To naziranje je pretrgal saški knez Friderik Modri, ki ga argumenti o Luthrovem »krivoverstvu" niso prepričali in je zahteval sodbo domačih strokovnjakov ter domače instance. Pred očmi je imel svojo univerzo v Wittenbergu, ki je trdno branila Luthrova stališča. Pri cesarju Karlu je dosegel, da je bila "Luthrova zadeva« sprejeta kot točka državnega zbora ter da je cesar Luthru garantiral varen prihod $\mathrm{v}$ Worms in povratek $\mathrm{v}$ Wittenberg. $\mathrm{Na} \mathrm{dr}-$ žavnem zboru je Luther nastopil 17. in 18. aprila. Stran, ki je zastopala Luthrovo obsodbo, je slednjemu dajala le možnost preklica obsojenih tez, zaradi česar je Luther prosil za premislek, kar je dosegel z osebnim cesarjevim dovoljenjem. Naslednji dan, 18. aprila, je Luther svoj nastop sijajno izpeljal, na kar je 19. aprila cesar osebno odgovoril. Tako sta si dobesedno stala nasproti cesar Karel in redovnik Luther, in to na državnem zboru, pred najvišjim državnim zastopstvom, kar je bilo dotlej popolnoma nepredstavljivo, kjer sta predočila vsak svoje versko občutje in dojemanje, s sklicevanjem na lastno vest. Bila sta v zelo neenakem položaju, ne le kot cesar in redovnik, temveč še v mnogo kočljivejši zadevi, cesar kot versko »svoboden« in Luther kot polnomočno obsojen ter izobčen »krivoverec«.

Luthrova zadeva na državnem zboru zdaleč ni bila čisto verske narave, temveč odraz širših družbeno-verskih razmer v prelomnem obdobju. Spor je kulminiral v nasprotjih med »kulturnim« Rimom in barbarskim "germanstvom«, kar odlično ponazarja korespondenca papeževega odposlanca Hieronima Aleandra. K velikemu razumevanju za Luthrov odpor do Rima so v državnem zboru pripomogle več desetletij stare nemške pritožbe (lat. gravamina), o katerih so razpravljali na državnih zborih, ki jih v Rimu niso jemali resno. 
Sicer pa so bili glavni dejavniki pri zadevi Luther (causa Lutheri) na državnem zboru: Martin Luther, cesar Karel V., saški knez Friderik Modri ter poseben papežev odposlanec Hieronim Aleandro. Čeprav je vsak od imenovanih odšel iz državnega zbora s svojo "zmago", je bil dejanski zmagovalec Martin Luther, ki je dosegel dotlej neviden uspeh že s tem, da je na državnem zboru nastopil, da ni preklical obsojenih tez in da se je lahko s cesarjevo zaščito vrnil v Wittenberg. Res je svoje temeljne reformne spise objavil že leta 1520, vendar se je pot reformaciji odprla šele sedaj. Na povratku »ugrabljen« se je lotil prevoda Svetega pisma v nemščino, ki je postalo edino priznana verska osnova, v prevod pa je vtkal svojo teologijo. Za sporočilo vere je uporabil domač, nemški jezik. To je demonstriral že v državnem zboru, kjer je govoril najprej nemško in šele nato, za tiste, ki nemško niso razumeli, kot na primer cesar in papežev legat Aleandro, v latinščini. V nemščini so prenašali dogajanje v državnem zboru tudi letaki (nem. Flugschriften) na ulici.

Za Luthra na prvi pogled zaključek državnega zbora ni bil ugoden, saj je wormški edikt, ki ga je cesar podpisal 26. maja, datiran pa je bil z 8. majem, kot akt cesarja in ne kot sklep državnega zbora, uzakonil Luthrovo obsodbo. Edikt je izdelal legat Aleandro, sodeloval pa je tudi kasnejši Trubarjev učitelj Peter Bonomo. Vendar edikt za Luthra ni imel usodnih posledic, ker cesar edikta ni poslal v deželo Saško in ga posledično knezu Frideriku ni bilo treba razglasiti, tako da tam, kjer je »krivoverec« bival, edikt ni veljal. $S$ tem pa je bilo Luthru omogočeno nadaljnje delo tako verskega reformatorja kot tudi univerzitetnega profesorja na univerzi v Wittenbergu, ki je postala osrednja ustanova za izobraževanje reformatorjev Luthrove smeri.

Ključne besede: wormški edikt, Friderik Modri, Karel V., Hieronim (Girolamo) Aleandro, Albrecht Brandenburški

\section{On the $5^{\circ 0^{\text {th }}}$ Anniversary of Luther's Appearance at the Diet of Worms}

Following the publication of Luther's theses on 31 October 1517, the Diet of Worms was the next fundamental step in the reform movement of the $16^{\text {th }}$-century European Christianity. In the "Holy Roman Empire," the way was opened for further religious and new institutional development in the previously unified church, culminating in the Peace of Augsburg in 1555, which granted individual rulers of political units in the country, princes, prince-bishops etc. the right to decide on the religion of their Catholic and Lutheran subjects.

The immediate cause of "Worms 1521" and the consequent "Edict of Worms" were two papal bulls addressed to Luther. The first, Exsurge Domine from 1520, threatened him with excommunication unless he recanted almost one half of the theses published in 1517. Luther responded by proclaiming the pope the Antichrist, although he had until then somewhat avoided criticising him, and publicly burned the bull in December of the same year. Exsurge Domine was followed in January 1521 by the bull Decet Roma- 
num Pontificem excommunicating Luther, which also meant death sentence and exile from the state.

According to the established doctrine and practice the execution of the sentence would follow automatically. This doctrine was rejected by Frederick the Wise, Elector of Saxony, who was not convinced by the arguments about Luther's "heresy" and demanded judgement by domestic experts and authorities. He had his University of Wittenberg in mind, which firmly defended Luther's views. Frederick the Wise reached the agreement with Emperor Charles that "the case of Luther" would be discussed at the Diet, and that Luther was guaranteed safe arrival in Worms and return to Wittenberg. Luther appeared before the Diet on April 17 and 18. The party representing Luther's conviction gave him only the option of renouncing the convicted theses, which is why he requested more time for reconsideration and was granted the emperor's personal permission. The next day, on April 18, Luther performed brilliantly, to which the emperor personally responded on April 19. Thus, Emperor Charles and the monk Luther literally stood opposite each other at the Diet, in front of the highest representatives of the state, which was previously completely unimaginable. Both presented their religious perceptions and understandings, referring to their own conscience. They were in a very unequal position not only as emperor and monk; it was a much more sensitive matter, since the emperor was religiously "free" while Luther was a validly convicted and excommunicated "heretic".

The case of Luther at the Diet was far from solely religious in nature, but rather a reflection of the broader socio-religious situation at the turning point in history. The conflict culminated in the contradictions between "cultural" Rome and barbaric "Germanism", as perfectly illustrated by the correspondence of the papal nuncio, Girolamo Aleandro the elder. The great understanding for Luther's resistance to Rome was supported at the Diet by decades-old German complaints (gravamina) debated at Diets, which were not taken seriously in Rome.

The most notable figures in the case of Luther (causa Lutheri) at the Diet were: Martin Luther, Emperor Charles V, Elector of Saxony Frederick the Wise, and the papal nuncio Girolamo Aleandro the elder. Although at the end of the Diet each of them was "victorious" in one way or another, the actual winner was Martin Luther, who achieved unprecedented success only by appearing before the Diet, not renouncing the convicted theses and being able to return to Wittenberg under the emperor's protection. It is true that he published his fundamental reform writings as early as 1520, but the door for the Reformation has only now opened. After Luther was "abducted" on his way back, he undertook the translation of the Bible into German, which became the only recognized religious basis, and he incorporated his theology into the translation. He used his native, German language to communicate the faith. This was already demonstrated at the Diet, where he spoke first in German and only then in Latin for those who did not understand German, e.g. the emperor and the papal nuncio Aleandro. Pamphlets (Flugschriften) handed out in the streets also reported about the events at the Diet in German. 
At first glance, the conclusion of the Diet was not favorable for Luther. The Edict of Worms, dated May 8 and signed by the emperor on May 26, as an act of the emperor and not as a resolution of the Diet, legitimized Luther's conviction. The edict was drafted by the nuncio Aleandro, and partly also by Peter Bonomo, later Trubar's teacher. However, the edict did not have fatal consequences for Luther, because the emperor did not send it to the province of Saxony; consequently Frederick, Elector of Saxony, did not have to declare it, so the edict did not apply where the "heretic" lived. This, in turn, enabled Luther to continue working as both a religious reformer and a university professor at the University of Wittenberg, which became a central institution for the education of $\mathrm{Lu}$ theran reformers.

Keywords: Edict of Worms, Frederick the Wise, Charles V., Girolamo Aleandro the elder, Albert of Brandenburg

\section{Zum 500. Jahrestag von Luthers Auftritt auf dem Reichstag zu Worms}

Nach der Veröffentlichung von Luthers Thesen am 31. Oktober 1517 stellt der Reichstag zu Worms den nächsten grundlegenden Schritt in der Reformbewegung des europäischen Christentums des 16. Jahrhunderts dar. Dadurch wurde im „Heiligen Römischen Reich", der Weg frei für eine religiöse Weiterentwicklung und eine neue institutionelle Entwicklung in der bisher einheitlichen Kirche. Der Höhepunkt wurde mit dem Augsburger Religionsfrieden von 1555 erreicht, der den einzelnen Landesherren, Fürsten, Fürstbischöfen usw. das Recht zuerkannte, über die Religion der Untertanen zu entscheiden und festzulegen, ob sie nach der katholischen Lehre oder dem lutherischen Bekenntnis leben sollten.

Der unmittelbare Anlass für „Worms 1521“ und für das darauffolgende „Wormser Edikt" waren zwei an Luther gerichtete päpstliche Bullen. In der ersten Bannandrohungsbulle Exsurge Domine aus dem Jahr 1520 wurde Luther zum Widerruf von knapp der Hälfte seiner 1517 veröffentlichten Thesen aufgefordert, worauf Luther den Papst, über den er bisher keine direkte Kritik geäußert hatte, zum Antichristen erklärte und die Bulle im Dezember desselben Jahres öffentlich verbrannte. Der Bannbulle von 1520 folgte im Januar 1521 eine zweite Bulle Decet Romanum Pontificem, mit der Luther exkommuniziert wurde, was das Todesurteil und die Reichsacht bedeutete.

Gemäß der damaligen Auffassung und Praxis sollte automatisch die Vollstreckung des Urteils erfolgen. Doch diese Auffassung wurde vom Kurfürsten von Sachsen, Friedrich dem Weisen, nicht geteilt. Ihn überzeugten die Argumente zu Luthers Häresie nicht und er forderte das Urteil der sächsischen Sachverständigen und der heimischen Instanz. Er hatte seine Universität zu Wittenberg vor Augen, die Luthers Ansichten fest verteidigte. Bei Kaiser Karl erreichte er, dass der Fall Luther (Causa Lutheri) zu den zu verhandelnden Punkten des Reichstags wurde und dass der Kaiser Luther eine sichere Ankunft in Worms und eine Rückkehr nach Wittenberg garantierte. Luther sprach am 17. und 18. April vor dem Reichstag. Die Partei, die sich für Luthers Verurteilung einsetzte, 
räumte Luther lediglich die Möglichkeit ein, seine umstrittenen Thesen zu widerrufen; daraufhin wurde ihm vom Kaiser eine eintägige Bedenkfrist gewährt. Am nächsten Tag, dem 18. April, folgte der großartige Auftritt Luthers, worauf der Kaiser am 19. April persönlich eine Antwort gab. So standen sich Kaiser Karl und der Mönch Luther buchstäblich gegenüber. Und dies auf dem Reichstag, vor der höchsten Reichsvertretung, was bis dahin völlig unvorstellbar gewesen war. Hier legte jeder der beiden Protagonisten seine eigenen religiösen Gefühle und Wahrnehmungen dar, wobei er sich auf das eigene Gewissen berief. Sie waren in einer sehr ungleichen Lage, nicht nur als Kaiser und Mönch, sondern in einer viel schwierigeren Angelegenheit, nämlich der Kaiser als religiös "frei“ und Luther als ein rechtskräftig verurteilter und exkommunizierter „Ketzer“.

Die Causa Lutheri auf dem Reichstag zu Worms war keineswegs rein religiöser Natur, sondern es spiegelten sich darin umfassendere gesellschaftlich-religiöse Zustände einer Wendezeit. Die Auseinandersetzung kulminierte im Konflikt zwischen dem „kulturellen" Rom und einem barbarischen "Germanentum“, was aus der Korrespondenz des päpstlichen Gesandten Hieronymus Aleander deutlich hervorgeht. Zum großen Verständnis für Luthers Widerstand gegen Rom trugen im Reichstag auch etliche jahrzehntealte deutsche Beschwerden (Gravamina nationis germanicae) bei, die im Reichstag diskutiert, jedoch in Rom nicht ernst genommen wurden.

Und so kam es dazu, dass zu den Haupakteuren im Fall Luther auf dem Reichstag zu Worms Martin Luther, Kaiser Karl V., der sächsische Kurfürst Friedrich der Weise und der päpstliche Sondergesandte Hieronymus Aleander gehörten. Obwohl jeder der Protagonisten auf dem Reichstag zu Worms seinen eigenen „Sieg“ feierte, war der eigentliche Gewinner Martin Luther, der einen beispiellosen Erfolg bereits dadurch erzielte, dass er auf dem Reichstag zu Worms auftrat, dass er seine Thesen nicht zurücknahm und dass ihm Kaiserschutz gewährt wurde, um nach Wittenberg zurückzukehren. Obwohl Luther seine grundlegenden Reformschriften bereits 1520 veröffentlichte, war der Weg zur Reformation erst jetzt geebnet. Der auf der Rückreise „entführte“ Luther nahm sich daraufhin die Übersetzung der Bibel ins Deutsche vor, die zur einzigen anerkannten religiösen Grundlage wurde, und er ließ seine Theologie in die Übersetzung einfließen. Um seinen Glauben zu vermitteln, bediente er sich seiner deutschen Muttersprache; ihre Bedeutung demonstrierte er bereits auf dem Reichstag zu Worms, als er zuerst Deutsch sprach und erst danach, für diejenigen, die kein Deutsch verstanden, wie z. B. der Kaiser und der Papstlegat Aleander, auf Lateinisch. Auf Deutsch wurden auch die Flugblätter und -schriften gedruckt, die auf der Straße verteilt wurden und über das Geschehen zu Worms informierten.

Auf den ersten Blick war der Ausgang des Reichstages für Luther ungünstig, da das vom Kaiser am 26. Mai unterzeichnete und auf den 8. Mai datierte Wormser Edikt, das aber ein Akt des Kaisers und kein Beschluss des Reichstags war, Luthers Verurteilung legitimierte. Das Edikt wurde vom Legaten Aleander verfasst, bei dem Entstehen des Textes nahm aber auch der spätere Lehrer Trubars, Peter Bonomo, teil. Doch hatte das Edikt für Luther keine fatalen Folgen, da es vom Kaiser nicht nach Sachsen übersandt wurde und der sächsische Kurfürst folglich nicht daran gebunden war, die Reichsacht 
über Luther in Sachsen zu verhängen. Somit konnte der „Ketzer“ in Sachsen unbehelligt verbleiben, da das Edikt dort nicht in Kraft trat. Dies wiederum ermöglichte es Luther, sich sowohl als Reformator als auch als Professor an der Universität zu Wittenberg zu betätigen, die zu einer zentralen Einrichtung für die Ausbildung von Reformatoren der lutherischen Ausrichtung wurde.

Schlüsselwörter: Wormser Edikt, Friedrich der Weise, Karl V., Hieronymus Aleander (Girolamo Aleandro), Albrecht von Brandenburg

\section{UDC 811.112.2"15“:929Luther M. 811.163.6"15“:929Trubar P.}

\section{Fanika Krajnc-Vrečko}

\section{Jezik kot posoda Duha pri Luthru in Trubarju}

Razprava osvetljuje pojmovanje oziroma razumevanje narodnega jezika dveh pomembnih osebnosti reformacije 16. stoletja, in to nemškega reformatorja Martina Luthra ter slovenskega protestanta in najpomembnejšega reformatorja Primoža Trubarja. Obema avtorjema jezik služi kot osnovno orodje za oznanjevanje evangelija, pri čemer evangelij prevajata $\mathrm{v}$ materni jezik. To uresničujeta s prevajanjem Biblije in vsak na svoj način utemeljujeta rabo maternega jezika kot sredstva, po katerem se uteleša Božji Duh. Tako Luther kot Trubar utrjujeta biblično besedilo v novodobnih evropskih jezikih, in to Luther v novi visoki nemščini, Trubar pa v slovenskem jeziku, ki se do njegovih tiskanih besedil poprej ni pojavljal v knjigah. Oba avtorja sta izdelala vsak svoj jezikovni program, ki ju je mogoče vzporejati ter iz njiju prepoznati jezikovni nazor obeh protestantov, ki temelji na spoznanju, da se je Bog poslužil jezikov, ko je hotel, da se evangelij širi med vse ljudi.

Ključne besede: Martin Luther, Primož Trubar, Biblija, prevajanje, jezikovni nazor, teološka antropologija

\section{Luther and Trubar's View on Language as the Vessel of the Spirit}

The discussion sheds light on the conception or understanding of the national language of two prominent personalities of the $16^{\text {th }}$-century Reformation: the German reformer Martin Luther and the Slovene Protestant and most important reformer Primož Trubar. For both authors, language serves as a basic tool for preaching the gospel in their mother tongues. They accomplish this by translating the Bible, and they each in their own way justify the use of the mother tongue as the means through which the Spirit of God is embodied. Both Luther and Trubar consolidate the biblical text in early modern European languages: Luther in the New High German and Trubar in the 
Slovene language, which had not appeared in books until the publication of his printed texts. Both authors developed their own language programme that can be compared and from which both Protestants' view on language can be discerned, which was based on the realization that God used languages when he wanted the gospel to spread among all people.

Keywords: Martin Luther, Primož Trubar, Bible, translating, view on language, theological anthropology

\section{Sprache als Gefäß des Geistes bei Luther und Trubar}

Die Abhandlung beleuchtet die Auffassung von Nationalsprache bei zwei bedeutenden Persönlichkeiten der Reformation des 16. Jahrhunderts, nämlich bei dem deutschen Reformator Martin Luther und dem slowenischen Protestanten und wichtigsten slowenischen Reformator Primož Trubar. Die Sprache dient beiden Autoren als grundlegendes Werkzeug der Verkündigung des Evangeliums, das sie durch die Bibelübersetzung in ihre jeweilige Muttersprache übertragen. Der Gebrauch der Muttersprache als Mittel, durch das der Geist Gottes sich verkörpert, wird von jedem der beiden Reformatoren auf eigene Art und Weise gerechtfertigt. Sowohl Luther als auch Trubar verankern den biblischen Text in den modernen europäischen Sprachen, Luther im Neuhochdeutschen und Trubar in der slowenischen Sprache, welche bis zu seinen gedruckten Texten noch nicht in Büchern aufgetaucht war.

Die beiden Autoren haben eigene, vergleichbare Sprachprogramme, welche miteinander vergleichbar und aus denen die Sprachansichten beider Protestanten zu erkennen sind. Sie gründen auf der Erkenntnis, dass Gott sich der Sprachen bediente, um das Evangelium unter allen Menschen zu verbreiten.

Schlüsselwörter: Martin Luther, Primož Trubar, Bibel, Übersetzung, Sprachansicht, theologische Anthropologie

Prevod povzetkov $v$ angleščino: Višnja Jerman Prevod povzetkov v nemščino: Tanja Žigon Bibliografska obdelava: Helena Lemut 